\title{
Pluchea indica: An updated review of its botany, uses, bioactive compounds and pharmacological properties
}

\author{
Eric Wei Chiang Chan ${ }^{1 *}$, Ying Ki Ng1, Siu Kuin Wong², Hung Tuck Chan ${ }^{3}$ \\ 1 Faculty of Applied Sciences, UCSI University, Cheras, Kuala Lumpur, Malaysia \\ 2 School of Foundation Studies, Xiamen University Malaysia, Sepang, Selangor, Malaysia \\ 3 Secretariat of International Society for Mangrove Ecosystems (ISME), Faculty of Agriculture, University of the Ryukyus, Okinawa 903-0129, Japan
}

\begin{abstract}
In this article, the botany, uses, bioactive compounds and pharmacological properties of leaves and roots of Pluchea indica are reviewed for the first time. The coastal species occurs in open sites at the landward side of mangroves. Main botanical characters for the identification of $P$. indica are bushy shrub life-form, and leaves are short-stalked, obovate, thick papery, tapering base and serrated margin. Crushed leaves are very aromatic. Its traditional uses take the form of medicine and food. The pharmacological properties of $P$. indica are focused on its antioxidant, antibacterial, anti-cancer and anti-inflammatory activities. Caffeoylquinic acids and terpene glycosides are the main bioactive compounds from aerial parts and leaves of $P$. indica, respectively. Antioxidant properties of $P$. indica leaves have been reported to be stronger than those of Curcuma longa turmeric rhizomes. Also reported is that $P$. indica tea has stronger antioxidant properties of than green tea of Camellia sinensis. Leaves and roots of $P$. indica including tea leaves inhibit the growth of Gram-positive and Gramnegative bacteria, and possess anti-inflammatory properties. Roots are cytotoxic to cancer cells. Leaves and roots of $P$. indica also possess a range of other bioactivities. Some future research and prospects are suggested.
\end{abstract}

\section{Keywords:}

Indian camphorweed, Antioxidant, Antibacterial, Anti-cancer, Anti-inflammatory

\section{INTRODUCTION}

Coastal plants are those growing on muddy shores, sandy beaches and rocky promontories. Represented by a wide array of trees, shrubs, vines and epiphytes, they have important ecological and environmental values such as coastal protection and habitats for fauna. Coastal flora are also important food and medicinal plants.

Pluchea indica (L.) Less., one of the coastal plants, was chosen for the review since it has been utilized as sources of food and medicine. Its extracts exhibit several pharmacological activities promoting human health benefits. The botany, bioactive compounds and pharmacological properties of $P$. indica are reviewed for the first time. The pharmacological properties including antioxidant, antibacterial, anti-cancer, anti-inflammatory and other activities, are summarized. To date, there is only a review on the nutrition, health benefits and applications of $P$. indica leaves ${ }^{1}$. Three other reviews emphasized on the phytochemistry and biological activities of the genus Pluchea Cass $^{2-4}$.

Sources of information procured for this review were from Google Scholar, PubMed, PubMed Central, Science Direct, J-Stage, JSTOR, PubChem and Directory of Open Access Journals (DOAJ). The primary keywords for search are Pluchea indica and the secondary keywords include constituents, antioxidant, cancer, etc.

\section{BOTANY AND USES}

Pluchea indica (L.) Less. (syn. Baccharis indica) of the family Asteraceae (previously named as Compositae) is a bushy coastal shrub that grows up to 2 meters in height. Common names of $P$. indica are Indian camphorweed and Indian fleabane. Vernacular names are beluntas in Malaysia and Indonesia, khlu in Thailand,

\section{*Corresponding author:}

*Eric Wei Chiang Chan chanwc@ucsiuniversity.edu.my; erchan@yahoo.com 


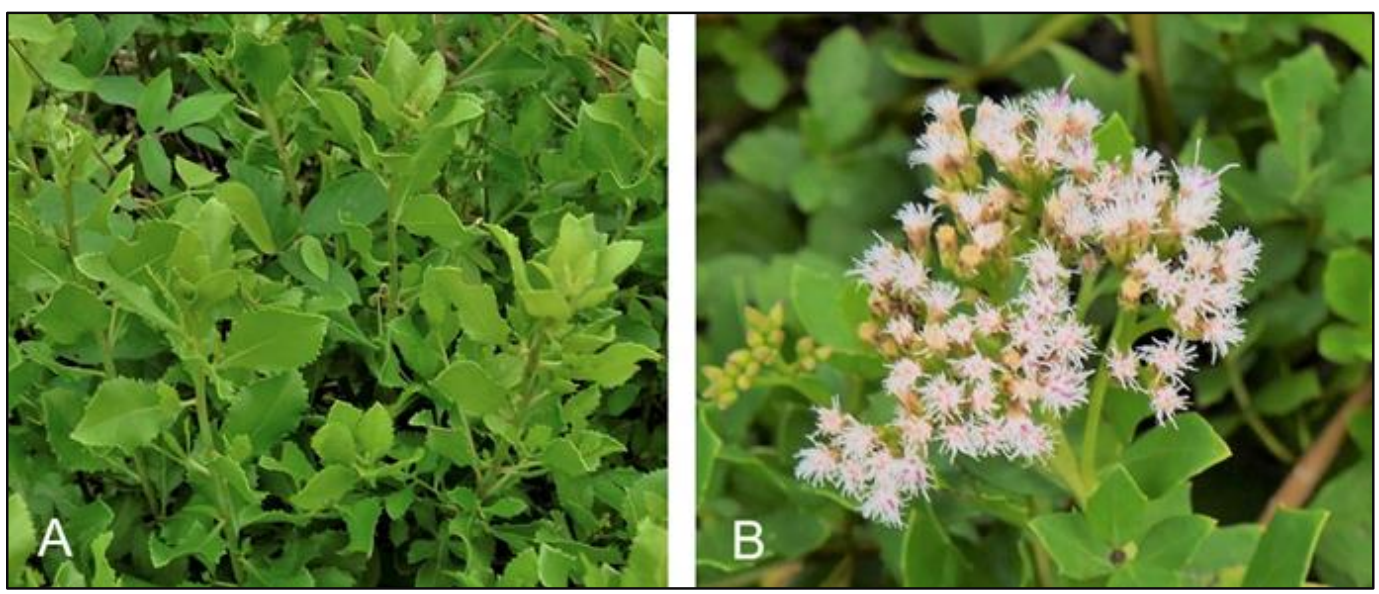

Figure 1. Leaves (A) and flowers (B) of Pluchea indica.

and kuo bao ju in China ${ }^{1,5}$.

Leaves of $P$. indica are short-stalked, obovate, thick papery and have a tapering base and serrated margin (Figure 1). Leaves are bright green when young, pale green when mature, and very aromatic when crushed. Flowers are disk-shaped, corolla is 5-lobed, tubular and violet in color, and anthers are also violet and extend beyond the petals. The marginal florets are female while the central florets are bisexual but functionally staminate. Flowering occurs throughout the year. Fruits are top-shaped, ribbed, one-seeded and indehiscent. The species occurs in open sites at the landward side of mangroves especially on bunds surrounding shrimp ponds or salt pans. Geographically, P. indica occurs from India to southern China and Taiwan, throughout Southeast Asia and stretches to northern Australia and Polynesia. It is native to tropical and subtropical Asia and has been introduced to the Pacific, including Hawaii ${ }^{5-7}$.

Traditional uses of $P$. indica in the form of medicine and food have been reported in countries of Southeast and South Asia. In Indonesia and Malaysia, the leaves are used as a traditional remedy for stomach ache, cough, dysentery and leucorrhoea. In Indonesia, leaves are mixed with other ingredients into poultice for ulcers, sores and rheumatic pains. In Thailand, different plant parts of $P$. indica are used as a diuretic for treatment of kidney stones, ulcers, lumbago and leucorrhoea. A plant paste is applied externally to treat skin diseases and hemorrhoid. In Vietnam, a decoction of the roots or leaves is used for treating fever, headache, rheumatism, sprains, dysentery and dyspepsia. A decoction of fresh leaves is used as inhalant to cure colds. In Vietnam and Cambodia, leaves of $P$. indica are crushed in alcohol for treating lumbago. In India roots astringent and antipyretic $^{1,7}$.

In Malaysia, Indonesia and Thailand, leaf shoots of aromatic herbs including $P$. indica are consumed as ulam, a Malay word for traditional salad ${ }^{8-9}$. They form an important component of the traditional diet. Ulam herbs are consumed raw or blanched as a side-dish and condiment for flavoring. Besides whetting the appetite during meals, the regular intake of ulam herbs is believed to have health-promoting properties ${ }^{8-9}$. In Vietnam and Cambodia, an infusion of $P$. indica leaves is consumed as tea ${ }^{7}$. Khlu tea is has been commercially available in Thailand as a health-promoting drink ${ }^{1,8-9}$.

\section{BIOACTIVE COMPOUNDS}

The main constituents of aerial parts and leaves of $P$. indica are caffeoylquinic acids, phenolic acids, flavonoids and thiophenes (Table 1). Recently, from the aerial parts, 20 caffeoylquinic acids, 19 phenolic acids, 14 flavonoids and 12 thiophenes have been reported ${ }^{10-12}$. Other scientists have also reported the presence of flavonoids from the leaves ${ }^{13-14}$ and thiophenes from aerial parts ${ }^{15-16}$ of $P$. indica.

Caffeoylquinic acids are esters of caffeic and quinic acids ${ }^{17}$. Phenolic acids are derivatives of benzoic acid $\left(\mathrm{C}_{6}-\mathrm{C}_{1}\right)$ and cinnamic acid $\left(\mathrm{C}_{6}-\mathrm{C}_{3}\right)$ while flavonoids are ubiquitous phenolic compounds having a $\mathrm{C}_{6}-\mathrm{C}_{3}-\mathrm{C}_{6}$ skeleton in which two benzene rings are linked by a $\mathrm{C}_{3}$ ring $^{18}$. Thiophenes are five-membered heterocyclic $\mathrm{C}_{4} \mathrm{H}_{4} \mathrm{~S}$ compounds containing a sulphur atom ${ }^{19}$.

Caffeoylquinic acids (CQAs) of $P$. indica included CQAs ${ }^{20-22}$, diCQAs ${ }^{20-24}$, triCQAs ${ }^{23,25}$ and tetra$\mathrm{CQAs}^{23,25}$. CQAs included 3-CQA (chlorogenic acid), 4-CQA (cryptochlorogenic acid), and 5-CQA (neochlorogenic acid) (Table 1). DiCQAs included 1,3-diCQA, 1,4-diCQA, 1,5-diCQA, 3,4-diCQA, 3,5-diCQA and 4,5-diCQA. TriCQA were represented by 1,3,4-triCQA, 1,3,5-triCQA and 3,4,5-tri- $O$-CQA, while tetraCQA included 1,3,4,5-tetra- $O$-CQA. Methyl esters of triCQA and tetraCQA have also been reported ${ }^{23}$. Chemical structures of CQAs, diCQAs, triCQA and tetraCQA are shown in Figure 2. Among the phenolic acids in the leaves of $P$. indica, the content of 3-CQA $(20.0 \mathrm{mg} / 100 \mathrm{~g})$ was the highest followed by caffeic acid $(8.65 \mathrm{mg} / 100$ $\mathrm{g})^{14}$. The contents of CQAs were highest in the juvenile leaf shoots of $P$. indica 
Table 1. Main chemical constituents of aerial parts and leaves of $P$. indica.

\begin{tabular}{|c|c|c|c|c|}
\hline No. & Compound type & Compound name & Plant part & Reference \\
\hline 1 & \multirow{27}{*}{$\begin{array}{l}\text { Caffeoylquinic } \\
\text { acids }\end{array}$} & 3-Caffeoylquinic acid (3-CQA) & Aerial & $12,20-22$ \\
\hline 2 & & 4-Caffeoylquinic acid (4-CQA) & Aerial & $12,20-22$ \\
\hline 3 & & 5-Caffeoylquinic acid (5-CQA) & Aerial & $12,20-22$ \\
\hline 4 & & 1,3-di- $O$-Caffeoylquinic acid (1,3-diCQA) & Aerial & 12 \\
\hline 5 & & 1,4-di- $O$-Caffeoylquinic acid (1,4-diCQA) & Aerial & 12 \\
\hline 6 & & 1,5-di- $O$-Caffeoylquinic acid (1,5-diCQA) & Aerial & 12 \\
\hline 7 & & \multirow[t]{2}{*}{ 3,4-di-O-Caffeoylquinic acid (3,4-diCQA) } & Aerial & 12 \\
\hline & & & Leaves & $20-24$ \\
\hline \multirow[t]{2}{*}{8} & & \multirow[t]{2}{*}{ 3,5-di-O-Caffeoylquinic acid (3,5-diCQA) } & Aerial & 12 \\
\hline & & & Leaves & $20-24$ \\
\hline \multirow[t]{2}{*}{9} & & \multirow[t]{2}{*}{ 4,5-di-O-Caffeoylquinic acid (4,5-diCQA) } & Aerial & 12 \\
\hline & & & Leaves & $20-24$ \\
\hline 10 & & Ethyl 3,4-di- $O$-caffeoyl quinate & Aerial & 12 \\
\hline 11 & & Ethyl 3,5-di- $O$-caffeoyl quinate & Aerial & 12 \\
\hline 12 & & Methyl 3-O-caffeoyl quinate & Aerial & 12 \\
\hline 13 & & Methyl 3,4-di-O-caffeoyl quinate & Aerial & 12 \\
\hline 14 & & Methyl 3,5-di- $O$-caffeoyl quinate & Aerial & 12 \\
\hline \multirow[t]{2}{*}{15} & & \multirow[t]{2}{*}{ Methyl 4,5-di- $O$-caffeoyl quinate } & Aerial & 12 \\
\hline & & & Leaves & 23 \\
\hline \multirow[t]{2}{*}{16} & & \multirow[t]{2}{*}{ Methyl 3,4,5-tri- $O$-caffeoyl quinate } & Aerial & 12 \\
\hline & & & Leaves & 23 \\
\hline \multirow[t]{2}{*}{17} & & \multirow[t]{2}{*}{ 1,3,4,5-tetra- $O$-Caffeoylquinic acid (1,3,4,5-tetraCQA ) } & Aerial & 12 \\
\hline & & & Leaves & 23,25 \\
\hline 18 & & 1,3,4-tri- $O$-Caffeoylquinic acid (1,3,4-triCQA) & Aerial & 12 \\
\hline 19 & & 1,3,5-tri- $O$-Caffeoylquinic acid (1,3,5-triCQA) & Aerial & 12 \\
\hline \multirow[t]{2}{*}{20} & & \multirow[t]{2}{*}{ 3,4,5-tri- $O$-Caffeoylquinic acid (3,4,5-triCQA) } & Aerial & 12 \\
\hline & & & Leaves & 23,25 \\
\hline 1 & \multirow{19}{*}{$\begin{array}{l}\text { Phenolic } \\
\text { acids }\end{array}$} & trans-Caffeic acid & Aerial & 10 \\
\hline 2 & & trans-Coniferyl aldehyde & Aerial & 10 \\
\hline 3 & & Dibutylphthalate & Aerial & 10 \\
\hline 4 & & 3,4-Dihydroxybenzaldehyde & Aerial & 10 \\
\hline 5 & & 3,4-Dihydroxybenzoic acid & Aerial & 10 \\
\hline 6 & & 2,3-Dihydroxy-1-(4-hydroxy-3-methoxyphenyl)-propan-1-one & Aerial & 10 \\
\hline 7 & & 3,4-Dihydroxy-5-methoxybenzaldehyde & Aerial & 10 \\
\hline 8 & & $\begin{array}{l}\text { (-)-(7S,7'S,8R,8'R)-4,4'-Dihydroxy-3,3',5,5'-pentamethoxy-7,9': 7', 9-diepoxy- } \\
\text { lignane }\end{array}$ & Aerial & 10 \\
\hline 9 & & Esculetin & Aerial & 10 \\
\hline 10 & & Ethyl caffeate & Aerial & 10 \\
\hline 11 & & trans-Ferulic acid & Aerial & 10 \\
\hline 12 & & $p$-Hydroxybenzoic acid & Aerial & 10 \\
\hline 13 & & (+)-Isolariciresinol & Aerial & 10 \\
\hline 14 & & $(+)-9$ '-Isovaleryllariciresinol & Aerial & 10 \\
\hline 15 & & erythro-2,3-bis-(4-Hydroxy-3-methoxyphenyl)-3-ethoxypropan-1-ol & Aerial & 10 \\
\hline 16 & & threo-2,3-bis(4-Hydroxy-3-methoxyphenyl)-3-ethoxypropan-1-ol & Aerial & 10 \\
\hline 17 & & 3-Methoxy-4-hydroxybenzoic acid & Aerial & 10 \\
\hline 18 & & Syringicaldehyde & Aerial & 10 \\
\hline 19 & & Vanillin & Aerial & 10 \\
\hline 1 & Flavonoids & Casticin & Aerial & 11 \\
\hline 2 & & Centaureidin & Aerial & 11 \\
\hline 3 & & Chrysosplenol C & Aerial & 11 \\
\hline 4 & & Cynaroside & Aerial & 11 \\
\hline 5 & & Isorhamnetin & Aerial & 11 \\
\hline \multirow[t]{2}{*}{6} & & \multirow[t]{2}{*}{ Kaempferol } & Aerial & 11 \\
\hline & & & Leaves & 13,14 \\
\hline 7 & & Kaempferol 3-O- $\beta$-D-glucopyranoside (astragalin) & Aerial & 11 \\
\hline 8 & & Luteolin & Aerial & 11 \\
\hline 9 & & Myricetin & Leaves & 13,14 \\
\hline 10 & & Quercetin & Aerial & 11 \\
\hline
\end{tabular}


Table 1. Main chemical constituents of aerial parts and leaves of $P$. indica.(cont.)

\begin{tabular}{|c|c|c|c|c|}
\hline No. & Compound type & Compound name & Plant part & Reference \\
\hline & Flavonoids & Quercetin & Leaves & 13,14 \\
\hline 11 & & Quercetin-3-O- $\beta$-D-galactopyranoside & Aerial & 11 \\
\hline 12 & & Quercetin-3-O- $\beta$-D-glucopyranoside & Aerial & 11 \\
\hline 13 & & 5,7,3',4'-Tetrahydroxy-3-methoxyflavonol-3'- $O$ - $\beta$-D-glucopyranoside & Aerial & 11 \\
\hline 14 & & 5,6,4'-Trihydroxy-3,7-dimethoxyflavone & Aerial & 11 \\
\hline 1 & Thiophenes & 2-(3-Acetoxy-4-hydroxybut-1-yn-1-yl)-5-(penta-1,3-diyn-1-y1) thiophene & Aerial & 15 \\
\hline 2 & & 2-(3,4-Dihydroxybut-1-yn-1-yl)-5-(penta-1,3-diyn1-yl) thiophene & Aerial & 15 \\
\hline 3 & & 3"-Ethoxyl-(3"S)-pluthiophenol & Aerial & 11 \\
\hline 4 & & 3"-Ethoxyl-(3"S)-pluthiophenol-4"-acetate & Aerial & 11 \\
\hline 5 & & $\begin{array}{l}\text { 2-(4-O- } \beta \text {-Glucopyranosyl-3-hydroxybut-1-yn-1-yl)-5-(penta-1,3-diyn-1-yl) } \\
\text { thiophene }\end{array}$ & Aerial & 15 \\
\hline 6 & & 2-(4-Hydroxy-3-methoxybut1-yn-1-yl)-5-(penta-1,3-diyn-1-yl) thiophene & Aerial & 15 \\
\hline 7 & & 2-(Penta-1,3-diyn-1-yl)-5-(4-acetoxy-3-hydroxybuta-1-yn-1-yl) thiophene & Aerial & 16 \\
\hline 8 & & (3"R)-Pluthiophenol & Aerial & 11 \\
\hline 9 & & (3"R)-Pluthiophenol-4"-acetate & Aerial & 11 \\
\hline 10 & & 2-(Prop-1-inyl)-5-(6-acetoxy-5-hydroxyhexa-1,3-diinyl) thiophene & Aerial & 16 \\
\hline 11 & & 2-(Prop-1-inyl)-5-(5,6-dihydroxyhexa-1,3-diinyl) thiophene & Aerial & 16 \\
\hline 12 & & 2-(Prop-1-yn-1-yl)-5-(6-acetoxy-5-hydroxyhexa-1,3-diyn-1-yl) thiophene & Aerial & 15 \\
\hline
\end{tabular}

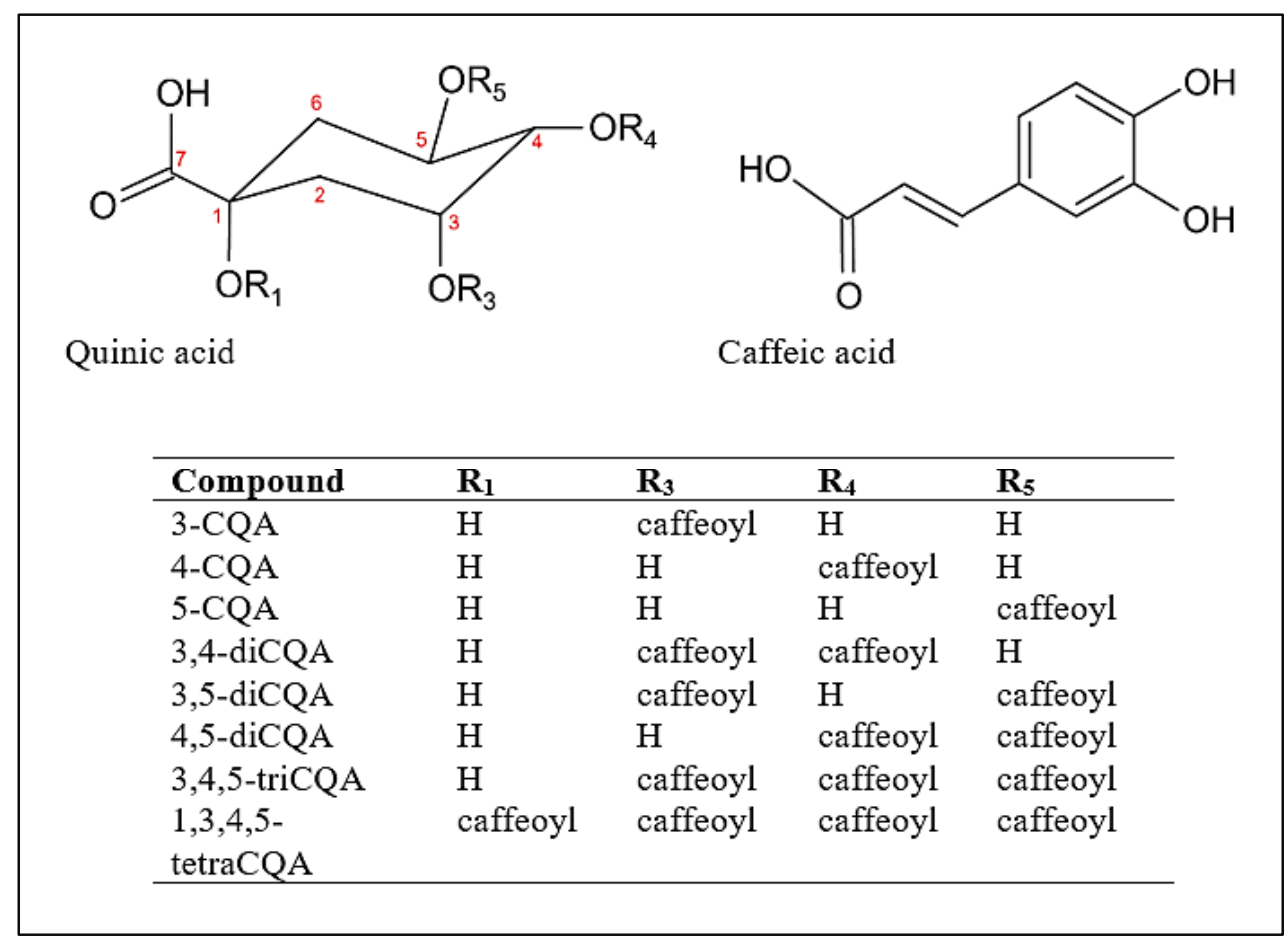

Figure 2. Chemical structures of caffeoylquinic acids (CQAs) and derivatives.

compared to mature leaves before flowering and mature leaves during flowering ${ }^{22}$. In the juvenile leaf shoots, 4,5-diCQA (19-28\%) was the dominant CQA, followed by 3,5-diCQA (6.2-12\%) and 3-CQA (3.4-7.3\%). The contents of CQAs depend on the extraction methods used $^{21}$. Highest yield was obtained using ultrasound with 50\% ethanol and the results were 4,5-diCQA (31\%) followed by 3-CQA (19\%) and 3,5-diCQA (13\%). From the leaves of $P$. indica, flavonoids included quercetin, myricetin and kaempferol ${ }^{13-14}$. Their contents were 5.21, 0.90 and $0.28 \mathrm{mg} / 100 \mathrm{~g}$, respectively. From the twigs of $P$. indica in Vietnam, stigmasterol, 1-eicosanoyl gly- cerol, 2-(prop-1-ynyl)-5-(5,6-dihydroxyhexa-1,3-diynyl)thiophene, stigmasterol 3-O- $\beta$-D-glucopyranoside and $\beta$-sitosterol 3-O- $\beta$-D-glucopyranoside have been isolated $^{26}$. The essential oil of $P$. indica leaves yielded 66 components ${ }^{27}$. Dominant components were $(10 S, 11 S)$ himachala-3-(12)-4-diene (17\%) and caryophyllene (12\%). With regard to the chemical constituents of roots of $P$. indica, meagre work has been done. Pioneering investigation afforded the isolation of a new monoterpene glycoside (plucheoside $\mathrm{C}$ ), three new eudesmane-type sesquiterpenes (plucheols A \& B, and plucheoside E) and three new lignan glycosides (plu- 
cheosides $\left.\mathrm{D}_{1}, \mathrm{D}_{2} \& \mathrm{D}_{3}\right)^{28}$. Later, two new thiophene derivatives and two new pentacyclic triterpenes ${ }^{29}, \mathrm{R} / \mathrm{J} / 3$, a pure compound ${ }^{30}$, and PITC-2, a new thiophene derivative $^{31}$ have been identified.

\section{PHARMACOLOGICAL PROPERTIES}

\subsection{Antioxidant activities}

Out of 11 types of herbs studied, P. indica ranked second to Cosmos caudatus Kunth in terms of antioxidant activities as measured by 2,2-diphenyl-1picrylhydrazyl (DPPH) radical scavenging, ferric reducing power (FRAP), and 2,2'-azino-bis(3-ethylbenzothiazoline-6-sulfonic acid (ABTS) radical scavenging, and inhibition of linoleic acid oxidation ${ }^{13}$. FRAP and DPPH radical scavenging of $P$. indica leaves were 4 and 2 times those of rhizomes of Curcuma longa $\mathrm{L}$. (turmeric) $^{32}$. When the antioxidant properties of different parts of $P$. indica extracted with different solvents, the strongest DPPH radical scavenging were from the methanol leaf extract ${ }^{33}$. Ranking in DPPH radical scavenging were methanol leaf extract > methanol stem extract > hexane leaf extract > hexane stem extract. Another study reported that polar solvents such as methanol yielded the strongest DPPH radical scavenging and $\mathrm{FRAP}^{34}$. As follow-up, lemon juice was added to $P$. indica tea aimed at improving the sensory properties of the tea ${ }^{35}$. Results showed that citric acid and ascorbic acid from the lemon juice could hydrolyze the glycoside bonds or ester bonds of phytochemical compounds in $P$. indica tea. The product from hydrolyzation caused enhancement of antioxidant and antidiabetic activities.

Amongst $P$. indica ethanol leaf extracts of different development stages, the juvenile leaf shoots had the strongest antioxidant activities (based on DPPH, ABTS and FRAP assays) compared to mature leaves before flowering and mature leaves during flowering ${ }^{22}$. The stronger antioxidant activities of juvenile leaf shoots may be attributed to their significantly higher concentrations of the bioactive and phenolic compounds. Out of three CQAs and three diCQAs, strongest DPPH and ABTS radical scavenging was 5-CQA and 4,5-diCQA, respectively. 3,4-diCQA and 4,5-diCQA had the strongest FRAP activity ${ }^{22}$.

Results of a comparison of antioxidant activities based on DPPH radical scavenging of ethanol extracts of different parts of $P$. indica showed highest values were the roots. Ranking of DPPH radical scavenging was roots $>$ stems $>$ twigs $>$ flowers $\sim$ leaves ${ }^{36}$. Values in DPPH radical scavenging of dried samples were lower than those of fresh samples, possibly due to degradation of phenolic compounds during the extended drying process (oven drying at $60^{\circ} \mathrm{C}$ for 2 days). Antioxidant properties of $P$. indica tea leaves (young leaves pan fried at $50^{\circ} \mathrm{C}$ for $2 \mathrm{~h}$ ) were stronger than oven-dried leaves. Recently, the antioxidant activities of $P$. indica tea were compared to those of green tea of Camellia sinensis (L.) Kuntze ${ }^{37}$. The $P$. indica leaf tea exhibited stronger DPPH and nitric oxide (NO) radical scavenging but weaker ABTS radical scavenging than green tea. Surprisingly, the tea infusions were brewed using hot phosphate buffer saline (PBS) instead of using hot water.

In another comparative study, methanol and hexane extracts of leaves and stems of $P$. indica were analyzed for total phenolic content and DPPH radical scavenging activity ${ }^{33}$. Results showed that the methanol leaf extract possessed the highest content (574 mg GAE/ $100 \mathrm{~g})$ and strongest activity $\left(\mathrm{IC}_{50}=24.5 \mu \mathrm{g} / \mathrm{ml}\right)$. The hexane stem extract possessed the lowest content (63 $\mathrm{mg} \mathrm{GAE} / 100 \mathrm{~g})$ and weakest activity $\left(\mathrm{IC}_{50}=402 \mu \mathrm{g} / \mathrm{ml}\right)$.

\subsection{Antibacterial activities}

Ethanol extracts of different parts of $P$. indica were tested for their antibacterial properties using Gram-positive Bacillus cereus, Pseudomonas fluorescens and Staphylococcus aureus, and Gram-negative Escherichia coli and Salmonella typhimurium ${ }^{36}$. Antibacterial properties were based on diameter inhibition zone and minimum inhibitory concentration. Fresh roots, stems and twigs inhibited the growth of all five species of bacteria tested. Inhibition of dried samples was weaker than that of fresh samples. Tea leaves of $P$. indica (prepared by pan frying young leaves at $50^{\circ} \mathrm{C}$ for $2 \mathrm{~h}$ ) also inhibited the growth of all species of bacteria tested. Another in vitro study suggested the potential of aqueous extract of ground dried aerial parts of $P$. indica for urinary tract infection treatment by its inhibitory effect towards Klebsiella pneumoniae and $E$. $\operatorname{coli}^{38}$. An in vivo study reported that the methanol root extract of $P$. indica administered to mice at doses of 0.5 and $1.0 \mathrm{mg} / \mathrm{kg}$ body weight significantly protected the animals with typhoid fever caused by S. typhimurium ${ }^{39}$. The antibacterial properties of $P$. indica have attracted scientists to develop topical antibiotics such as roll-on deodorant ${ }^{40}$ and foot-spray ${ }^{41}$.

\subsection{Anti-cancer properties}

The crude aqueous extracts of $P$. indica roots and leaves are cytotoxic to GBM8401 brain glioblastoma and HeLa cervical cancer cells via suppression of cell proliferation, viability and migration ${ }^{42}$. Treatment with the extracts at various concentrations for 48 hours resulted in $75 \%$ and $70 \%$ inhibition on proliferation and viability of GBM8401 and HeLa cells, respectively. It was found that phosphorylated-p53 and -p21 were induced in GBM8401 and HeLa cells. In HeLa cells, apoptosis was promoted and the expression of phos- 
phorylated-AKT decreased. In anti-cancer activities, phosphorylated-p53 and -p21 are critical tumor suppressor molecules that decrease the expression of phosphorylated-AKT, an important survival signaling molecule ${ }^{42}$.

The hexane fraction of $P$. indica root extract inhibited proliferation and induced autophagy in U87 glioblastoma cells ${ }^{43}$. Cell proliferation was suppressed by induction of cell cycle arrest and autophagy. There was significant up-regulation of acidic vesicular organelle (AVO). The expression levels of microtubuleassociated light chain 3-II (LC3-II) protein, phosphorylated c-Jun N-terminal kinase (JNK) and phosphorylated p38 were significantly increased, confirming the occurrence of autophagy during the process ${ }^{43}$. The root extract combined with LY294002 (pan-PI3K inhibitor) further decreased cell viability, suggesting an additive anti-cancer effect. The ethanol root extract of $P$. indica induced apoptosis, anti-proliferation and migration in NPC-TW 01 and NPC-TW 04 nasopharyngeal carcinoma cells ${ }^{44}$. The strong anti-cancer activity of the root extract was attributed to the up-regulation of p53 and Bcl-2-associated X (Bax), and to the down-regulation of B-cell lymphoma 2 (Bcl-2) proteins.

The anti-cancer properties of the root extract of tissue-cultured $P$. indica against Ehrlich ascites carcinoma cells in mice have also been reported ${ }^{45}$. PITC-2 (a thiophene) isolated from the root extract of tissuecultured $P$. indica inhibited the growth of sarcoma- 180 cancer cells in mice ${ }^{46}$.

\subsection{Anti-inflammatory properties}

Early studies have reported on the antiinflammatory properties of the root extract of $P$. indica in rats and mice ${ }^{47}$. The anti-inflammatory properties involve the 5-lipooxygenase pathway ${ }^{48}$ and have a protective effect against gastric damage ${ }^{49}$. Besides having anti-inflammatory effects, the ethanolic leaf extract of $P$. indica also possesses antinociceptive properties ${ }^{50}$.

Hot water extract of $P$. indica tea had potent inhibitory effects against lipopolysaccharide-induced NO and prostaglandin E2 production in RAW 264.7 macrophages with $\mathrm{IC}_{50}$ values of 315 and $49 \mu \mathrm{g} / \mathrm{ml}$, respectively ${ }^{51}$. Recently, the ethanol extract of $P$. indica tea leaves was reported to exhibit anti-inflammatory effects on tumour necrosis factor (TNF) $\alpha$-induced endothelial cells by reduction of reactive oxygen species (ROS) production and decreasing the expression of ICAM-1 and VCAM-1 proteins that is mediated partly through the up-regulation of heme oxygenase-1 (HO$1)^{52}$. A follow-up study on the molecular mechanisms underlying the anti-inflammatory activities of $P$. indica leaves in RAW 264.7 macrophages involved the inhibition of NO production and suppression of inducible nitric oxide synthase (iNOS), mediated via the suppression of NF-kB activation but not the phosphorylation of mitogen-activated protein kinase (MAPK) ${ }^{53}$.

\subsection{Other properties}

Other pharmacological properties of $P$. indica are listed in Table 2. They include $\alpha$-glucosidase inhibitory, collagenase inhibitory, matrix metalloproteinase inhibitory, acetylcholinesterase inhibitory, antinociceptive, analgesic, anti-diabetic, anti-obesity, antiulcer, hepatoprotective, lipid-lowering, adipogenesis inhibitory, hypoglycemic, neuropharmacological, CNS depressant, venom neutralizing, wound healing and diuretic activities.

\section{CONCLUSIONS}

Caffeoylquinic acids and terpene glycosides are the main bioactive compounds from leaves and roots of $P$. indica, respectively. Antioxidant properties of $P$. indica leaves have been reported to be stronger than those of $C$. longa rhizomes. Also reported is that $P$. indica tea has stronger antioxidant properties of than green tea of $C$. sinensis. Leaves and roots of $P$. indica including tea leaves inhibit the growth of Gram-positive and Gram-negative bacteria, and possess anti-inflammatory properties. Roots are cytotoxic to cancer cells. Leaves and roots of $P$. indica also possess a range of other bioactivities. There are prospects to develop useful products such as $P$. indica tea, including antibiotic deodorant, foot-spray, cream, gel, etc. Among others, further research is needed for the following aspects: 1 . To isolate and identify bioactive compounds from roots of $P$. indica as information is meagre. Furthermore, there is no information on bioactive compounds from flowers and fruits of $P$. indica. Therefore, there are prospects for encountering novel compounds. 2. To develop innovative drying protocols of $P$. indica leaves to produce the tea without affecting the antioxidant and sensory properties since extended oven-drying reduces antioxidant activities by degrading phenolic compounds. 3. To evaluate appropriate additives to $P$. indica tea aimed at improving its sensory properties and other bioactivities, 4 . To conduct more clinical trials on $P$. indica as there is only one trial to date, and 5. To develop derivatives of compounds with enhanced bioactivities e.g., anti-cancer properties via structure-activity relationship (SAR) studies.

\section{ACKNOWLEDGEMENT}

The authors are grateful to Prof. Shigeyuki Baba for taking the photos of leaves and flowers of $P$. indica in Chanthaburi, Thailand.

\section{Conflict of interest}

The authors have no conflict of interest to declare . 
Table 2. Other pharmacological activities of Pluchea indica.

\begin{tabular}{|c|c|c|c|}
\hline Activity & $\begin{array}{l}\text { Plant part/ } \\
\text { product }\end{array}$ & Description & Reference \\
\hline$\alpha$-Glucosidase inhibition & Leaf & $\begin{array}{l}\text { Activity was in the following order: juvenile leaf shoots > mature leaves } \\
\text { before flowering > mature leaves during flowering. }\end{array}$ & 22 \\
\hline$\alpha$-Glucosidase inhibition & Leaf & $\begin{array}{l}\text { A SAR study showed that inhibition by CQAs depends on both methyl } \\
\text { esterification of quinic acid and the number of caffeate groups in the } \\
\text { molecule. }\end{array}$ & 23 \\
\hline $\begin{array}{l}\text { Collagenase and MMP } \\
\text { inhibition }\end{array}$ & Leaf & $\begin{array}{l}\text { 3,4,5-TriCQA and 1,3,4,5-tetraCQA inhibited collagenase, and 1,3,4,5- } \\
\text { tetraCQA inhibited MMP-2 and -9. }\end{array}$ & 25 \\
\hline AChE inhibition & Leaf and stem & Methanol and hexane extracts were detected to have inhibitory properties. & 33 \\
\hline Anti-ulcer activity & Root & $\begin{array}{l}\text { Activity of extract involved decrease of gastric volume and acidity, and } \\
\text { protection of the gastric mucosa in rats, possibly due to inhibition of the } \\
\text { 5-LOX pathway. }\end{array}$ & 48 \\
\hline Antinociceptive effect & Leaf & $\begin{array}{l}\text { Extract exerted peripheral effect in acetic acid-induced writhing test on } \\
\text { mice. }\end{array}$ & 50 \\
\hline Anti-ulcer activity & Root & $\begin{array}{l}\text { Extract possessed significant activity in rats and guinea pigs by affording } \\
\text { protection against gastric lesions. }\end{array}$ & 54 \\
\hline Analgesic activity & Root & Infusion had $77.5 \%$ of pain reduction at $29 \mathrm{mg} / 20 \mathrm{~g}$ body weight of mice. & 55 \\
\hline $\begin{array}{l}\text { Hypoglycemic and } \\
\text { antihyperglycemic effects }\end{array}$ & Leaf & Extract exerted effects on streptozotocin-induced diabetic rats. & 56 \\
\hline Attenuated $\beta$-cell apoptosis & Leaf & Extract attenuated activity in streptozotocin-induced diabetic mice. & 57 \\
\hline Alleviated liver injury & Leaf & Extract alleviated injury in streptozotocin-induced diabetic mice. & 58 \\
\hline $\begin{array}{l}\text { Ameliorated hyperglycemia } \\
\text { and dyslipidemia }\end{array}$ & Tea & $\begin{array}{l}\text { In a clinical trial, tea lowered serum TG and LDL-C, and increased } \\
\text { serum HDL-C. }\end{array}$ & 59 \\
\hline Ameliorated obesity & Tea & $\begin{array}{l}\text { Tea reduced weight gain in high fat diet (HFD) mice, and is non- toxic } \\
\text { to the kidney, liver and blood. }\end{array}$ & 60 \\
\hline Hepatoprotective activity & Root & $\begin{array}{l}\text { Extract exhibited significant activity against } \mathrm{CCl}_{4} \text {-induced hepatotoxi- } \\
\text { city in rats and mice. }\end{array}$ & 61 \\
\hline Lipid lowering & Tea & $\begin{array}{l}\text { Tea decreased lipid accumulation, inhibited adipogenesis in 3T3-L1 } \\
\text { adipocytes and inhibited lipase activity. }\end{array}$ & 62 \\
\hline CNS depressant activity & Root & $\begin{array}{l}\text { Extract exerted potent activity in rats and mice via inhibition of spon- } \\
\text { taneous motility and prolongation of sleeping time. }\end{array}$ & 63 \\
\hline CNS depressant activity & Root & $\begin{array}{l}\text { Extract exerted potent activity in rats and mice that included muscle } \\
\text { relaxant, inhibition of aggressive behavior and increase brain GABA } \\
\text { concentration. }\end{array}$ & 64 \\
\hline Neuropharmacological effects & Root & $\begin{array}{l}\text { Extract had neuropharmacological effects on mice via decreased } \\
\text { locomotor activity and increased pentobarbital sleep. }\end{array}$ & 65 \\
\hline $\begin{array}{l}\text { Neutralized viper venom- } \\
\text { induced lethality }\end{array}$ & Root & $\begin{array}{l}\text { Methanol extract significantly neutralized viper venom-induced lethality } \\
\text { and haemorrhagic activity in mice. }\end{array}$ & 66 \\
\hline $\begin{array}{l}\text { Neutralized viper and cobra } \\
\text { venom }\end{array}$ & Root & $\begin{array}{l}\beta \text {-Sitosterol and stigmasterol from extract neutralized viper and cobra } \\
\text { venom. }\end{array}$ & 67 \\
\hline Wound healing & Root & $\begin{array}{l}\text { Tissue-cultured extract had potent activity in rats based on wound } \\
\text { contraction, epithelialization period, skin breaking strength and dry } \\
\text { granulation tissue weight. }\end{array}$ & 68 \\
\hline Wound healing & Leaf & $\begin{array}{l}\text { Extract containing nanoparticles displayed wound healing activity in } \\
\text { oral mucosal cells via oral spraying. }\end{array}$ & 69 \\
\hline Wound healing & Leaf & Extract at $80 \mathrm{~mol} / \mathrm{L}$ prevented hyperproliferation of fibroblasts. & 70 \\
\hline Wound healing & Leaf & $\begin{array}{l}\text { Extract accelerated activity in the oral mucosa by decreasing inflam- } \\
\text { matory cells and increasing collagen density. }\end{array}$ & 71 \\
\hline Diuretic effects & Leaf & Infusion exerted diuretic effects on both rats and human subjects. & 72 \\
\hline Diuretic effects & Leaf & Tissue-cultured extract had significant diuretic activity in rats. & 73 \\
\hline
\end{tabular}

$\mathrm{AChE}=$ acetylcholinesterase, $\mathrm{CCl}_{4}=$ carbon tetrachloride, $\mathrm{CNS}=$ central nervous system, $\mathrm{CQA}=$ caffeoylquinic acid, GABA=gamma aminobutyric acid, HDL=high-density lipoprotein, $\mathrm{HFD}=$ high fat diet, $\mathrm{LDL}=$ low-density lipoprotein, $\mathrm{LOX}=$ lipoxygenase, $\mathrm{MMP}=$ matrix metalloproteinase, $\mathrm{SAR}=$ structure-activity relationship, and TG=triglyceride. 


\section{Funding}

No funding to declare.

\section{Ethics approval}

None to declare.

\section{Article info:}

Received June 21, 2021

Received in revised form September 2, 2021

Accepted October 5, 2021

\section{REFERENCES}

1. Suriyaphan O. Nutrition, health benefits and applications of Pluchea indica (L.) Less leaves. Mahidol Univ J Pharm Sci. 2014;41(4):1-10.

2. Sharma SK, Goyal N. Biological studies of the plants from genus Pluchea. Ann Biol Res. 2011;2(3):25-34.

3. Ahemd SA, Kamel EM. Phenolic constituents and biological activity of the genus Pluchea. Der Pharm Chem. 2013;5(5):109-14.

4. Hussain H, Al-Harrasi A, Abbas G, Rehman NU, Mabood F, Ahmed I, et al. The genus Pluchea: Phytochemistry, traditional uses, and biological activities. Chem Biodivers. 2013;10:1944-71.

5. Shi Z, Chen Y, Chen Y, Lin Y, Liu S, Ge X, et al. Pluchea indica. In: Asteraceae. Flora of China. 2011;20-21:848.

6. Giesen W, Wulfraat S, Zieren M, Scholten L. Pluchea indica (L.) Less. In: Mangrove Guidebook for Southeast Asia. Bangkok, Thailand, and Wageningen, Netherlands: FAO and Wetlands International; 2007. p. 148.

7. Raharjo I, Horsten SFAJ. Pluchea indica (L.) Less. In: van Valkenburg JLCH, Bunyapraphatsara N, editors. Plant Resources of South-East Asia No. 12(2): Medicinal and Poisonous Plants 2. Leiden, The Netherlands: Backhuys Publisher; 2001. p. 441-3.

8. Chan EWC, Baba S, Chan HT, Kainuma M, Inoue T, Wong SK. Ulam herbs: A review on the medicinal properties of Anacardium occidentale and Barringtonia racemosa. J Appl Pharm Sci. 2017;7(2):241-7.

9. Chan EWC, Wong SK, Chan HT. Ulam herbs of Oenanthe javanica and Cosmos caudatus: An overview on their medicinal properties. J Nat Remedies. 2017;16:137-47.

10. Ruan J, Li Z, Yan J, Huang P, Yu H, Han L, et al. Bioactive constituents from the aerial parts of Pluchea indica Less. Molecules. 2018;23:2104.

11. Ruan JY, Xu YP, Qu L, Wang T, Yu HY, Zhang Y. Isolation and identification of flavonoids from aerial part of Pluchea indica Less. J Shenyang Jianzhu Univ (Nat Sci). 2018;35:607-10.

12. Ruan J, Yan J, Zheng D, Sun F, Wang J, Han L, et al. Comprehensive chemical profiling in the ethanol extract of Pluchea indica aerial parts by liquid chromatography/mass spectrometry analysis of its silica gel column chromatography fractions. Molecules. 2019;24:2784.

13. Andarwulan N, Batari R, Sandrasari DA, Bolling B, Wijaya H. Flavonoid content and antioxidant activity of vegetables from Indonesia. Food Chem. 2010;121(4):1231-5.

14. Andarwulan N, Kurniasih D, Apriady RA, Rahmat H, Roto AV, Bolling BW. Polyphenols, carotenoids, and ascorbic acid in underutilized medicinal vegetables. J Funct Foods. 2012;4(1): 339-47.

15. Qiu YQ, Qi SH, Zhang S. Thiophene derivatives from the aerial part of Pluchea indica. Heterocycles. 2008;75(7):1757-64.

16. Boonruang S, Prakobsri K, Pouyfung P, Srisook E, Prasopthum A, Rongnoparut P, et al. Inhibition of human cytochromes P450 2A6 and 2A13 by flavonoids, acetylenic thiophenes and sesquiterpene lactones from Pluchea indica and Vernonia cinerea. J Enzyme Inhib Med Chem. 2017;32(1):1136-42.

17. Chan EWC, Lim YY, Ling SK, Tan SP, Lim KK, Khoo MG. Caffeoylquinic acids from leaves of Etlingera species (Zingi- beraceae). LWT-Food Sci Technol. 2009;42(5):1026-30.

18. Kaurinovic B, Vastag D. Flavonoids and phenolic acids as potential natural antioxidants. In: Antioxidants. London, UK: IntechOpen; 2019. p. 20.

19. Sperry JB, Wright DL. Furans, thiophenes and related heterocycles in drug discovery. Curr Opin Drug Discov Dev. 2005; 8(6):723-40.

20. Shukri MM, Alan C, Noorzuraini AS. Polyphenols and antioxidant activities of selected traditional vegetables. J Trop Agric Food Sci. 2011;39(1):69-83.

21. Kongkiatpaiboon S, Chewchinda S, Vongsak B. Optimization of extraction method and HPLC analysis of six caffeoylquinic acids in Pluchea indica leaves from different provenances in Thailand. Rev Bras Farmacogn. 2018;28(2):145-50.

22. Vongsak B, Kongkiatpaiboon S, Jaisamut S, Konsap K. Comparison of active constituents, antioxidant capacity, and $\alpha$ glucosidase inhibition in Pluchea indica leaf extracts at different maturity stages. Food Biosci. 2018;25:68-73.

23. Arsiningtyas IS, Gunawan-Puteri MD, Kato E, Kawabata J. Identification of $\alpha$-glucosidase inhibitors from the leaves of Pluchea indica (L.) Less., a traditional Indonesian herb: Promotion of natural product use. Nat Prod Res. 2014;28:1350-3.

24. Chewchida S, Vongsak B. Simultaneous HPTLC quantification of three caffeoylquinic acids in Pluchea indica leaves and their commercial products in Thailand. Rev Bras Farmacogn. 2019; 29(2):177-81.

25. Ohtsuki T, Yokosawa E, Koyano T, Preeprame S, Kowithayakorn T, Sakai S, et al. Quinic acid esters from Pluchea indica with collagenase, MMP-2 and MMP-9 inhibitory activities. Phytother Res. 2008;22(2):264-6.

26. Giang PM. Sterol, glycerol ester, and thiophene constituents from the twigs of Pluchea indica L. of Vietnam. VNU J Sci. 2018;34(2):78-82.

27. Widyawati PS, Wijaya CH, Hardjosworo PS, Sajuthi D. Volatile compounds of Pluchea indica Less and Ocimum basilicum Linn essential oil and potency as antioxidant. HAYATI J Biosci. 2013;20(3):117-26.

28. Uchiyama T, Miyase T, Ueno A, Usmanghani K. Terpene and lignan glycosides from Pluchea indica. Phytochemistry. 1991; 30(2):655-7.

29. Chakravarty AK, Mukhopadhyay S. New thiophene derivatives from Pluchea indica. Ind J Chem. 1994;33:978-80.

30. Biswas R, Dutta PK, Achari B, Bandyopadhyay D, Mishra M, Pramanik $\mathrm{KC}$, et al. Isolation of pure compound $\mathrm{R} / \mathrm{J} / 3$ from Pluchea indica (L.) Less. and its anti-amoebic activities against Entamoeba histolytica. Phytomedicine. 2007;14:534-7.

31. Pramanik KC, Chatterjee TK. Isolation, characterization and sub-acute toxicity studies of a new compound PITC-2 isolated from tissue-cultured medicinal plant, Pluchea indica (L.) Less. Int J Biomed Pharm Sci. 2009;3(1):50-4.

32. Zabidi AR, Mohd Razif MA, Ismail SN, Sempo MW, Yahaya N. Antimicrobial and antioxidant activities in 'beluntas' (Pluchea indica), turmeric (Curcuma longa) and their mixtures. Sains Malay. 2020;49(6):1293-302.

33. Noridayu AR, Hii YF, Faridah A, Khozirah S, Lajis N. Antioxidant and anti-acetylcholinesterase activities of Pluchea indica Less. Int Food Res J. 2011;18(3):925-9.

34. Widyawati PS, Budianta TD, Kusuma FA, Wijaya EL. Difference of solvent polarity to phytochemical content and antioxidant activity of Pluchea indica Less leaves extracts. Int J Pharmacogn Phytochem Res. 2014;6(4):850-5.

35. Widyawati PS, Suseno TI, Utomo AR, Willianto TL, Yohanita C, Wulandar TA. Effect of lemon (Citrus limon L.) addition to Pluchea indica Less. beverage. Carpathian J Food Sci Technol. 2020;12(4):125-39.

36. Srimoon R, Ngiewthaisong S. Antioxidant and antibacterial activities of Indian marsh fleabane (Pluchea indica (L.) Less). KKU Res J. 2015;20(2):144-54.

37. Sirichaiwetchakoon K, Lowe GM, Eumkeb G. The free radical 
scavenging and anti-isolated human LDL oxidation activities of Pluchea indica (L.) Less. tea compared to green tea (Camellia sinensis). BioMed Res Int. 2020:4183643.

38. Sittiwet C. In vitro antimicrobial activity of Pluchea indica aqueous extract: the potential for urinary tract infection treatment. J Pharmacol Toxicol. 2009;4(2):87-90.

39. Pramanik KC, Chatterjee TK. In vitro and in vivo antibacterial activities of root extract of tissue cultured Pluchea indica (L.) Less. Orient Pharm Exper Med. 2008;8(3):295-301.

40. Komala O, Wiendarlina IY, Rizqiyana N. Antibacterial activity roll on deodorant with Pluchea indica (L.) leaf extract against Staphylococcus epidermidis in vitro. IOP Conf Ser: Earth Environ Sci. 2019;293:12031.

41. Farhamzah, Herli A, Mursal IL. Formulation and antibacterial activity test of foot spray with beluntas leaf ethanol extract (Pluchea indica L.). IOP Conf Ser: Mater Sci Eng. 2021;1071: 12013.

42. Cho JJ, Cho CL, Kao CL, Chen CM, Tseng CN, Lee YZ, et al. Crude aqueous extracts of Pluchea indica (L.) Less. inhibit proliferation and migration of cancer cells through induction of p53-dependent cell death. BMC Complement Altern Med. 2012; 12(1):265.

43. Cho CL, Lee YZ, Tseng CN, Cho J, Cheng YB, Wang KW, et al. Hexane fraction of Pluchea indica root extract inhibits proliferation and induces autophagy in human glioblastoma cells. Biomed Rep. 2017;7(5):416-22.

44. Kao CL, Cho J, Lee YZ, Cheng YB, Chien CY, Hwang CF, et al. Ethanolic extracts of Pluchea indica induce apoptosis and antiproliferation effects in human nasopharyngeal carcinoma cells. Molecules. 2015;20(6):11508-23.

45. Pramanik KC, Ghosh S, Midya DK, Chatterjee TK. Antitumor activity and antioxidant role of tissue-cultured Pluchea indica root against Herlich ascites carcinoma in Swiss albino mice. Int J Biomed Pharm Sci. 2008;2(1):47-50.

46. Goswami S, Debnath S, Karan S, Chatterjee TK. In vivo antitumor activity of phytochemical PITC-2 obtained from tissue cultured plant Pluchea indica on sarcoma-180 solid tumor mice model. Asian J Pharm Clin Res. 2018;11(4):211-8.

47. Sen T, Chaudhuri AN. Anti-inflammatory evaluation of a Pluchea indica root extract. J Ethnopharmacol. 1991;33:135-41.

48. Sen T, Ghosh TK, Chaudhuri AN. Studies on the mechanism of anti-inflammatory and anti-ulcer activity of Pluchea indicaprobable involvement of 5-lipooxygenase pathway. Life Sci. 1993;52(8):737-43.

49. Sen T, Ghosh TK, Bhattacharjee S, Nag Chaudhuri AK. Action of Pluchea indica methanol extract as a dual inhibitor on PAFinduced paw oedema and gastric damage. Phytother Res. 1996; 10(1):74-6.

50. Roslida A, Erazuliana A, Zuraini A. Anti-inflammatory and antinociceptive activities of the ethanolic extract of Pluchea indica (L.) Less leaf. Pharmacologyonline. 2008;2:349-60.

51. Srisook K, Buapool D, Boonbai R, Simmasut P, Charoensuk Y, Srisook E. Antioxidant and anti-inflammatory activities of hot water extract from Pluchea indica Less. herbal tea. J Med Plants Res. 2012;6(23):4077-8.

52. Srisook K, Jinda S, Srisook E. Anti-inflammatory and antioxidant effects of Pluchea indica leaf extract in TNF $\alpha$-induced human endothelial cells. Walailak J Sci Technol. 2021;18(10): 10271.

53. Buapool D, Mongkol N, Chantimal J, Roytrakul S, Srisook E, Srisook K. Molecular mechanism of anti-inflammatory activity of Pluchea indica leaves in macrophages RAW 264.7 and its action in animal models of inflammation. J Ethnopharmacol. 2013;146:495-504.

54. Pal S, Chaudhuri AN. Studies on the effects of Pluchea indica Less root extract on gastroduodenal ulcer models in rats and guinea pigs. Phytother Res. 1989;3(4):156-8.

55. Suhendy H, Priatna M, Iskandar Y. Analgesic activity of infusion of beluntas radix (Pluchea indica $\mathrm{L}$.) on the male mice.
In: Proceedings of the $2^{\text {nd }}$ Bakti Tunas Husada-Health Science International Conference (BTH-HSIC 2019); June 8; Atlantis Press; 2020. p. 258-60.

56. Pramanik KC, Bhattacharya P, Biswas R, Bandyopadhyay D, Mishra M, Chatterjee TK. Hypoglycemic and antihyperglycemic activity of leaf extract of Pluchea indica Less. Orient Pharm Exper Med. 2006;6:232-6.

57. Nopparat J, Nualla-Ong A, Phongdara A. Ethanolic extracts of Pluchea indica (L.) leaf pre-treatment attenuates cytokineinduced $\beta$-cell apoptosis in multiple low-dose streptozotocininduced diabetic mice. PloS One. 2019;14(2):e0212133.

58. Nopparat J, Nualla-Ong A, Phongdara A. Treatment with Pluchea indica (L.) Less. leaf ethanol extract alleviates liver injury in multiple low-dose streptozotocin-induced diabetic BALB/c mice. Exper Ther Med. 2020;20(2):1385-96.

59. Sirichaiwetchakoon K, Churproong S, Kupittayanant S, Eumkeb G. The effect of Pluchea indica (L.) Less. tea on blood glucose and lipid profile in people with prediabetes: A randomized clinical trial. J Altern Complement Med. 2021;27(8):669-77.

60. Sirichaiwetchakoon K, Lowe GM, Kupittayanant S, Churproong S, Eumkeb G. Pluchea indica (L.) Less. tea ameliorates hyperglycemia, dyslipidemia, and obesity in high fat diet-fed mice. Evid Based Complement Altern Med. 2020;2020:8746137.

61. Sen T, Basu A, Ray RN, Nag Chaudhuri AK. Hepatoprotective effects of Pluchea indica (Less.) extract in experimental acute liver damage in rodents. Phytother Res. 1993;7(5):352-5.

62. Sirichaiwetchakoon K, Lowe GM, Thumanu K, Eumkeb G. The effect of Pluchea indica (L.) Less. tea on adipogenesis in 3T3-L1 adipocytes and lipase activity. Evid Based Complement Altern Med. 2018;2018:4108787.

63. Mahapatra PK, Chaudhuri AK. Neuropharmacological studies on Pluchea indica. Planta Med. 1986;6:546-7.

64. Sen T, Chaudhuri AN. Studies on the neuropharmacological aspects of Pluchea indica root extract. Phytother Res. 1992;6(4): $175-9$.

65. Thongpraditchote S, Matsumoto K, Temsiririrkkul R, Tohda M, Murakami Y, Watanabe H. Neuropharmacological actions of Pluchea indica Less root extract in socially isolated mice. Biol Pharm Bull. 1996;19(3):379-83.

66. Alam MI, Auddy B, Gomes A. Viper venom neutralization by Indian medicinal plant (Hemidesmus indicus and Pluchea indica) root extracts. Phytother Res. 1996;10(1):58-61.

67. Gomes A, Saha A, Chatterjee I, Chakravarty AK. Viper and cobra venom neutralization by $\beta$-sitosterol and stigmasterol isolated from the root extract of Pluchea indica Less. (Asteraceae). Phytomedicine. 2007;14(9):637-43.

68. Pramanik KC, Chatterjee TK. Wound healing properties of tissue-cultured Pluchea indica (L.) Less. root extract in rats. Int J Biomed Pharm Sci. 2008;2(2):112-6.

69. Buranasukhon W, Athikomkulchai S, Tadtong S, Chittasupho C. Wound healing activity of Pluchea indica leaf extract in oral mucosal cell line and oral spray formulation containing nanoparticles of the extract. Pharm Biol. 2017;55(1):1767-74.

70. Maharani SC, Julianto I, Widhiati S. The role of beluntas (Pluchea indica Less.) leaf extract in preventing the occurrence of fibroblasts hyperproliferation: An in vitro preliminary study. Dermatol Rep. 2019;11:22-4.

71. Pranata N, Boli GE, Sinta R, Sugiaman VK. Effect of beluntas leaf extract (Pluchea indica) on oral mucosal wound healing in terms of density of inflammatory cells and collagen. Syst Rev Pharm. 2021;12(1):618-22.

72. Nilvises N, Vamnatjinda V, Vanveerakul B, Pidech P. Diuretic effect of Pluchea indica. Thai J Pharmacol. 1989;11:1-8.

73. Chatterjee TK. Tissue culture of the plant Pluchea indica (L.) Less. and evaluation of diuretic potential of its leaves. Orient Pharm Exper Med. 2007;7(2):197-204. 